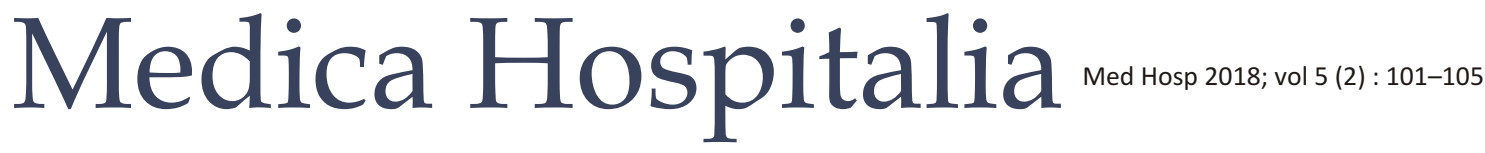

Original Article

\section{Pengaruh Vitamin C terhadap Peroksidasi Lipid, Gejala Klinik dan Kualitas Hidup Penderita Tonsilitis Kronik}

\author{
Nancy Liwikasari, Farokah, Suprihati \\ Departemen IKTHT-KL Fakultas Kedokteran Universitas Diponegoro/RSUP Dr. Kariadi Semarang
}

\begin{abstract}
Abstrak
Latar belakang : Masalah tonsilitis kronik sering pada anak. Gejala klinik yang muncul berdampak negatif sehingga menurunkan kualitas hidup. Radikal bebas berperan dalam tonsilitis kronik. Potensi kerusakan radikal bebas dibatasi antioksidan. Penelitian ini bertujuan untuk membuktikan vitamin $\mathrm{C}$ menurunkan kadar peroksidasi lipid, memperbaiki gejala klinik dan kualitas hidup penderita tonsilitis kronik.

Metode : Penelitian Randomized Controlled Trial dengan simple random sampling. Penilaian kadar peroksidasi lipid, gejala klinik dan kualitas hidup dilakukan sebelum dan sesudah pemberian vitamin C.

Hasil : Total 51 penderita, 10 drop out dan 41 dianalisis. Kadar peroksidasi lipid sesudah perlakuan kelompok vitamin $\mathrm{C}$ $(3,41(0,53-4,65))$ tidak berbeda bermakna dibandingkan sebelum perlakuan $(3,43(0,39-4,16))(p=0,237)$. Skor total gejala klinik sesudah perlakuan kelompok vitamin $C(14,76 \pm 4,34)$ lebih rendah dibandingkan sebelum perlakuan $(20,38 \pm 5,25)(p=0,000)$. Skor total kualitas hidup sesudah perlakuan kelompok vitamin $C$ $(65(52-79))$ lebih rendah dibandingkan sebelum perlakuan $(78(57-88))(p=0,000)$.

Simpulan : Kadar peroksidasi lipid yang diberikan vitamin C tidak berbeda bermakna dibandingkan tanpa diberikan vitamin $C$ $(p=0,237)$. Gejala klinik dan kualitas hidup yang diberikan vitamin Clebih baik dibandingkan tanpa diberikan vitamin $C$.
\end{abstract}

Kata kunci : tonsilitis kronis, kadar peroksidasi lipid, gejala klinik, kualitas hidup

\section{PENDAHULUAN}

Tonsilitis kronik merupakan suatu proses infeksi atau inflamasi tonsila palatina yang menetap, sebagaimana dikutip dari Farokah (2007). ${ }^{1}$ Data epidemiologi terkait tonsilitis kronik menurut Suwento (2001) prevalensi penyakit ini sebesar $3,8 \%$ pada 7 provinsi di Indonesia (1994-1996) setelah nasofaringitis akut (4,6\%). ${ }^{2}$ Masalah

\section{The influence of vitamin C to lipid peroxidation, clinical symptom and quality of life of chronic tonsilitis patients}

\begin{abstract}
Background: Chronic tonsillitis are often found in children. Clinical symptoms gives negative impact that decrease quality of life. Free radicals play role in chronic tonsillitis. Potential damage caused by free radicals is limited by an antioxidants. The objectives of this study was to prove vitamin C decrease lipid peroxidation, improve clinical symptoms and quality of life of chronic tonsillitis patients. Methods : Randomized Controlled Trial by simple random sampling. Rate levels of lipid peroxidation, clinical symptoms and quality of life before and after administration of vitamin C.

Results : Total 51 patients, 10 dropped out and 41 were analyzed. Lipid peroxidation of vitamin C group post-intervension (3.41 (0.53 to 4.65)) no significant difference betweenpre-intervension $(3.43(0,39-4,16))(p=0.237)$. Total score of clinical symptoms of vitamin C group post-intervension $(14.76 \pm 4.34)$ was lower than the pre-intervension $(20.38 \pm 5.25)(p=0.000)$. The total score quality of life of vitamin C group post-intervension (65 (52-79)) is lower than the pre-intervension $(78(57-88))(p=0.000)$.

Conclusion : The level of lipid peroxidation were given vitamin $\mathrm{C}$ no significant difference between without given vitamin $C(p=0.237)$. Clinical symptoms and quality of life were given vitamin $C$ is better than without given vitamin C.
\end{abstract}

Keywords : chronic tonsillitis, levels of lipid peroxidation, clinical symptoms, quality of life

kesehatan terkait penyakit tonsilitis kronik sering pada anak-anak. Perasaan mudah lelah dan lesu, sulit berkonsentrasi, rasa tidak enak di tenggorok, sulit menelan sampai sakit menelan, nafas atau mulut berbau merupakan beberapa gejala klinik yang sering dijumpai pada penyakit tonsilitis kronik, tidak jarang pada penderita juga muncul gangguan pada telinga dan gangguan tidur. ${ }^{3,4}$ 
Gejala klinik tonsilitis kronik ini jelas berdampak negatif pada penderita baik dalamberaktivitas maupun sekolah sehingga dapat menurunkan kualitas hidup penderita yang berdampak juga pada keluarganya. ${ }^{3}$ Penelitian sebelumnya tentang kualitas hiduppenderita tonsilitis kronik melaporkan bahwa terdapat hubungan positifdan bermakna antara gejala klinik dengan kualitas hidup, adanya perbaikan gejala klinik maka akan diikuti dengan peningkatan kualitas hidup (Quality of Life, QoL). ${ }^{5}$

Pengaruh mikrobial virus dan invasi bakterial serta adanya pengaruh non mikrobial seperti refluks esofagus, imunomodulator dan radikal bebas berperan dalam tonsilitis kronik. ${ }^{4}$ Radikal bebas merupakanmolekultidak stabil dan sangat reaktif sehingga dapat menyebabkan kerusakan jaringan terutama di membran sel. Potensi yang merusak akibat radikal bebas dibatasi oleh sejumlah antioksidan. ${ }^{6}$ Vitamin C merupakan antioksidan yang mudah menyumbangkan elektron untuk memecah reaksi berantai peroksidasi lipid. ${ }^{7,8}$

Tonsilitis kronik merupakan penyakit infeksi atau inflamasi kronik sehingga terdapat kemungkinan keseimbangan antara peroksidasi lipid dan antioksidan terlibat. ${ }^{3}$ Mohamed, Sabry, Ali, Al-Refaey (2012) dari hasil penelitiannya menemukan kadar malondialdehyde
(MDA) sebagai produk peroksidasi lipid kelompok tonsilitis kronik $=3,08 \pm 1,37 \mu \mathrm{mol} / \mathrm{L}$ lebih tinggi dibandingkan kelompok kontrol $=1,51 \pm 0,52 \mu \mathrm{mol} / \mathrm{L}$ $(p<0,05)$. Kadar asam askorbat kelompok tonsilitis kronik $=0,03 \pm 0,02 \mu \mathrm{mol} / \mathrm{L}$ lebih rendah dibandingkan kelompok kontrol $=0,28 \pm 0,11 \mu \mathrm{mol} / \mathrm{L}(p=0,000)$. MDA yang tinggi sebagai penanda stres oksidasi dan kadar antioksidan asam askorbat yang rendah pada tonsilitis kronik dibandingkan kelompok kontrol pada penelitian ini menunjukkan adanya keterlibatan radikal bebas dan antioksidan pada tonsilitis kronik dan disarankan untuk penelitian lebih lanjut untuk mengevaluasi kemungkinan peran terapi dalam mencegah tonsilitis berulang dan memberikan asam askorbat untuk membantu menormalkan ketidakseimbangan radikal bebas dan antioksidan yang terjadi. ${ }^{9}$

Abuhandan et al (2013) dalam penelitiannya mendapatkan adanya peningkatan Total Oxidant Status (TOS) $=30,5 \pm 8,8 \mu \mathrm{mol} \mathrm{H} 2 \mathrm{O} 2 \mathrm{Eqv} /$ Ldan penurunan Total Antioxidant Status (TAS) $=0,8 \pm 0,2 \mu \mathrm{mol} \mathrm{H} 2 \mathrm{O} 2 \mathrm{Eqv} / \mathrm{L}$ pada penderita tonsilitis kronik dibandingkan kelompok kontrol sebelum dilakukan tonsilektomi. Pertimbangan untuk memberikan antioksidan eksternal untuk menetralisasikan tingkat oksidan yang tinggi pada periode sebelum operasi tonsilektomi disarankan pada

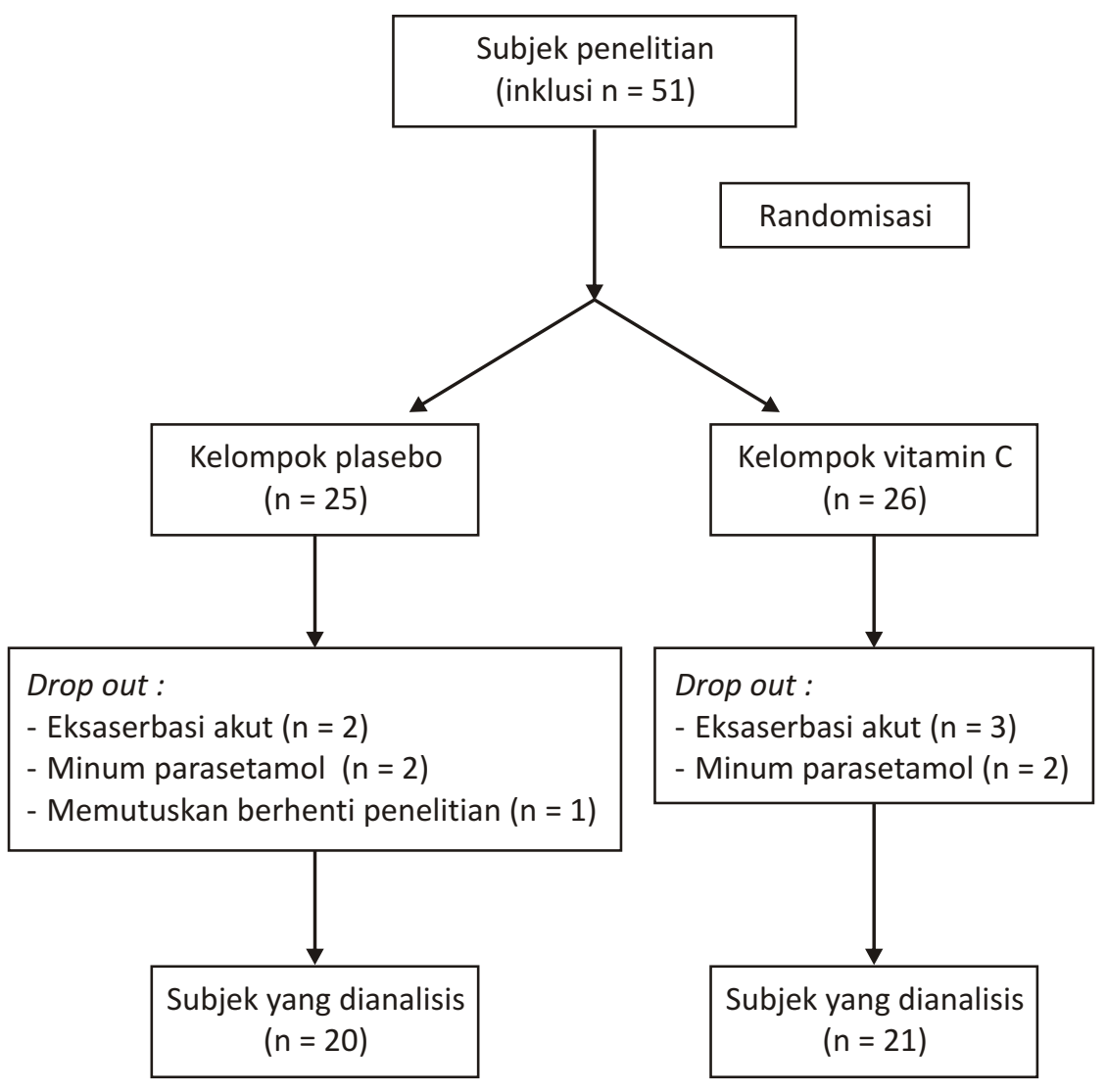

Gambar 1. Alur Penelitian 
hasil penelitian tersebut. ${ }^{10}$

Penelitian tentang pengaruh pemberian vitamin $C$ terhadap peroksidasi lipid, gejala klinik dan kualitas hidup penderita tonsilitis kronik di IKTHT-KL RSUP Dr. Kariadi Semarang belum pernah diteliti. Tujuan penelitian ini untuk membuktikan vitamin $C$ menurunkan kadar peroksidasi lipid, memperbaiki gejala klinik dan kualitas hidup penderita tonsilitis kronik.

\section{METODE}

Jenis penelitian ini eksperimental dengan desain Randomized Controlled Trial (RCT)dengan simple random sampling. Kelompok vitamin C dibandingkan dengan kelompok plasebo. Penilaian peroksidasi lipid, gejala klinik dan kualitas hidup dilakukan sebelum dan sesudah perlakuan.

Sampel penelitian ini adalah penderita tonsilitis kronik yang memenuhi kriteria inklusi dan kriteria eksklusi. Kriteria inklusi adalah penderita laki-laki atau perempuan berusia 5-18 tahun, memenuhi diagnosis tonsilitis kronik, status gizi normal dan rrang tua atau keluarga dan penderita bersedia ikut serta dalam penelitian sampai selesai dan menandatangani informed consent. Kriteria eksklusi adalah menderita penyakit kroniklain seperti rhinosinusitis kronik, otitis media supuratif kronik, laringitis kronik, gastritis kronik, penyakit sistemik seperti tuberkulosis, diabetes mellitus, sakit jantung, sakit ginjal. Kriteria drop-out adalah penderita memutuskan berhenti mengikuti penelitian, terjadi eksaserbasi akut, terdapat efek samping vitamin $\mathrm{C}$, tidak minum vitamin $\mathrm{C}$ dalam satu minggu berturutturut dan minum obat selain dari penelitian.

Analisis untuk membandingkan perbedaan kadar peroksidasi lipid, skor total gejala klinik dan skor total kualitas hidup tiap-tiap kelompok yang diberikan plasebo dan vitamin C menggunakan uji komparatif berpasangan Wilcoxon (non parametrik) untuk data berdistribusi tidak normal dan uji $\mathrm{T}$ berpasangan (parametrik) untuk distribusi data normal. Batas kemaknaan (a) untuk uji hipotesis dinyatakan pada $p<0,05$ dengan interval kepercayaan 95\%. Ethical clearance diperoleh dari Komisi Etik Penelitian Kedokteran Fakultas Kedokteran Universitas Diponegoro - RSUP Dr. KariadiSemarang.

\section{HASIL}

Subjek penelitian yang memenuhi kriteria inklusi sebesar 51 dan 41 subjek yang dianalisis.

Analisis inferensial dilakukan terhadap kadar peroksidasi lipid, skor total gejala klinik dan skor total kualitas hidup kelompok vitamin C dan plasebo.

\section{TABEL 1}

Kadar peroksidasi lipid kelompok vitamin C dan plasebo sebelum dan sesudah perlakuan

\begin{tabular}{lccc} 
Peroksidasi lipid & Sebelum perlakuan & Median & $p$ \\
\hline Vitamin C & $3,43(0,39-4,16)$ & $3,41(0,53-4,65)$ & $0,237^{*}$ \\
Plasebo & $3,94(0,11-5,24)$ & $3,89(0,10-5,07)$ & $0,955^{*}$ \\
& & $p=0,246^{* *}$ & \\
\hline
\end{tabular}

Keterangan :

* Uji Wilcoxon

** Uji Mann-Whitney

\section{TABE E 2}

Rerata skor total gejala klinik kelompok vitamin C dan plasebo sebelum dan sesudah perlakuan

$\begin{array}{lccc}\text { Skor total gejala klinik } & \text { Rerata } & & p \\ & \text { Sebelum perlakuan } & \text { Sesudah perlakuan } & 0,000^{*} \\ \text { Vitamin C } & 20,38 \pm 5,25 & 14,76 \pm 4,34 & 0,000^{*} \\ \text { Plasebo } & 18,65 \pm 5,17 & 15,05 \pm 5,14 & p=0,459 * *\end{array}$

Keterangan :

* Uji T berpasangan

** Uji T tidak berpasangan 


\section{TABEL 3}

Skor total kualitas hidup kelompok vitamin C dan plasebo sebelum dan sesudah perlakuan

Skor total kualitas hidup

Sebelum perlakuan
Median

Sesudah perlakuan $\boldsymbol{p}$

$\begin{array}{rcc}78(57-88) & 65(52-79) & 0,000^{*} \\ 72,5(57-87) & 67,5(52-80) & 0,001^{*} \\ & p=0,538^{* *} & \end{array}$

Keterangan :

* Uji Wilcoxon

** Uji Mann-Whitney

Efek samping pemberian vitamin $C$ yaitu gangguan gastrointestinal, mual, diare, nyeri perut dan iritasi kulit tidak ada yang dilaporkan selama penelitian.

\section{DISKUSI}

Hasil penelitian ini menunjukan kadar peroksidasi lipid sesudah perlakuan pada kelompok vitamin $C=3,41$ $(0,53-4,65) \quad \mu \mathrm{mol} / \mathrm{L}$ tidak berbeda bermakna dibandingkan sebelum perlakuan $=3,43(0,39-4,16)$ $\mu \mathrm{mol} / \mathrm{L}(p=0,237)$. Kadar peroksidasi lipid sesudah perlakuan pada kelompok plasebo $=3,89(0,10-5,07)$ $\mu \mathrm{mol} / \mathrm{L}$ tidak berbeda bermakna dibandingkan sebelum terapi $=3,94(0,11-5,24) \mu \mathrm{mol} / \mathrm{L}(p=0,955)$.

Penelitian peroksidasi lipid penderita tonsilitis kronik yang diberikan vitamin $\mathrm{C}$ belum pernah diteliti. Kadar peroksidasi lipid yang tidak berbeda bermakna sesudah pemberian vitamin $C$ pada penelitian ini dimungkinkan penambahan vitamin $\mathrm{C}$ sebagai antioksidan menyebabkan terjadinya peningkatan kadar antioksidan dalam darah yang secara tidak langsung menurunkan kadar oksidan darah penderita tonsilitis kronik, tetapi pada penelitian ini tidak diukur kadar vitamin $\mathrm{C}$ dalam darah, yang diperiksa adalah kadar peroksidasi lipid.

Hasil perubahan kadar peroksidasi lipid yang tidak berbeda bermakna dalam penelitian ini sesuai dengan Hirst, King, dan Pryde (2008) sebagaimana dikutip oleh Pashkow (2011) yang menyebutkan bahwa penelitian pemberian antioksidan dengan hasil tidak berbeda bermakna dimungkinkan akibat pemanfaatan oksigen sebagai bagian integral dari proses untuk menghasilkan energi metabolik (misalnya, terutama melalui rantai transpor elektron pada membran sel) juga menghasilkan ROS. ROS dapat cukup stabil untuk integritas membran dan memiliki fungsi penting pemeliharaan keseimbangan sinyal redoks intraseluler. Fungsi sistem antioksidan tidak untuk menghapus oksidan sepenuhnya, melainkan menjaga kadar oksidan tetap rendah agar tidak memicu kaskade inflamasi, serangkaian reaksi intraseluler dan intranuklear yang menandakan pelepasan sitokin inflamasi yang merusak. $^{11}$

Hasil penelitian ini menunjukan rerata skor total gejala klinik sesudah perlakuan pada kelompok vitamin $\mathrm{C}=14,76 \pm 4,34$ lebih rendah dibandingkan sebelum perlakuan $=20,38 \pm 5,25(p=0,000)$. Rerata skor total gejala klinik sesudah perlakuan pada kelompok plasebo $=$ $15,05 \pm 5,14$ lebih rendah dibandingkan sebelum perlakuan $=18,65 \pm 5,17(p=0,000)$.

Skor total kualitas hidup pasca terapi kelompok vitamin $C=65$ (52-79) lebih rendah dibandingkan sebelum perlakuan $=78(57-88)(p=0,000)$. Skor total gejala klinik sesudah perlakuan pada kelompok plasebo $=67,5(52-80)$ lebih rendah dibandingkan sebelum perlakuan $=72,5(57-87)(p=0,001)$.

Hasil penelitian ini sesuai Aleszczyk (2001) sebagaimana dikutip Mohamed, Sabry, Ali, Al-Refaey (2012) yang menyebutkan bahwa pada penderita tonsilitis kronik terbukti memiliki kadar antioksidan vitamin $\mathrm{C}$ yang rendah dibanding orang sehat dan penderita tonsilitis kronik ini mengalami penurunan sistem imun dan kemotaksis leukosit sehingga akan mempengaruhi timbulnya gejala klinik dan kualitas hidup. Peran pemberian vitamin $C$ dapat meningkatkan sistem imun dengan meningkatkan produksi dan efektivitas limfosit sehingga fagositosis meningkat. ${ }^{12}$

Tonsilitis kronis dengan atau tanpa hipertrofi adenoid merupakan penyakit yang sering menjadi penyebab anak-anak tidak hadir sekolah. Penyakit ini berdampak negatif terhadap kehidupan anak yang berpengaruh terhadap kualitas hidup anak-anak. Perasaan tidak enak badan, sulit berkonsentrasi, rasa tidak enak di tenggorok, sulit menelan sampai sakit menelan, gangguan napas, gangguan telinga dan gangguan tidur pada penderita tonsilitis kronik jelas akan menggangu aktifitas dan sekolah sehingga akan mempengaruhi kualitas hidup. ${ }^{3,4}$

Hemila, Al-Biltagi, Baset (2011) melaporkan efek pemberian vitamin $C$ selama 2 minggu terhadap perbaikan gejala penderita asma anak-anak usia 7 sampai 10 tahun berpengaruh terhadap peningkatan kualitas 
hidup penderita. Kelompok vitamin C mengalami perbaikan gejala klinik asma sesudah perlakuan sebesar 3 poin dibandingkan sebelum perlakuan $(p=0,004)$. Efek vitamin $C$ diduga dimediasi oleh pengaruh metabolism prostanoid pada proses inflamasi. ${ }^{13}$

Rerata skor total gejala klinik dan skor total kualitas hidup sesudah terapi pada kelompok plasebo yang lebih rendah dibandingkan sebelum terapi pada hasil penelitian ini dimungkinkan akibat adanya placebo effect. Wager dan Atlas (2015) menyebutkan bahwa placebo effect merupakan efek yang dapat diterima secara luas sebagai hasil dari pengobatan dan dapat meningkatkan kualitas hidup selama periode beberapa minggu, bulan atau lebih. Placebo effects ini dapat dihasilkan oleh adanya suatu sugesti, efek dari pengobatan sebelumnya, dan tanda sinyal bahwa plasebo tersebut merupakan obat aktif atau pengobatan telah diberikan. Informasi lengkap tentang tata cara pemberian obat, manfaat yang diharapkan dan edukasi tentang penyakitnya dalam banyak kasus menunjukan hasil klinis investigasi tentang placebo effect menunjukkan perbaikan fungsional penting yang disebabkan oleh interpretasi otak terhadap konteks pengobatan. ${ }^{14}$

Efek samping pemberian vitamin $\mathrm{C}$ dalam penelitian ini tidak didapatkan. Dosis yang diberikan sesuai dengan fungsi dan kebutuhan vitamin $C$ harian berdasarkan RDA dan tidak melebihi dosis maksimal. Pemberian lebih dari dosis maksimal akan menyebabkan efek samping yaitu adanya gangguan gastrointestinal seperti iritasi lambung, diare, eksresi cepat melalui urin, pembentukan batu di ginjal, insomnia, iritasi kulit dan absorbsi zat besi yang berlebihan. ${ }^{15}$

\section{SIMPULAN}

Kadar peroksidasi lipid yang diberikan vitamin $C$ tidak berbeda bermakna dibandingkan tanpa diberikan vitamin $C(p=0,237)$. Gejala klinik dan kualitas hidup yang diberikan vitamin $\mathrm{Clebih}$ baik dibandingkan tanpa diberikan vitamin C.

\section{DAFTAR PUSTAKA}

1. Farokah. Hubungan tonsilitis kronik dengan prestasi belajar pada siswa kelas II sekolah dasar di kota semarang. Cermin Dunia Kedokteran. 2007;155: p. 87-92.

2. Suwento R. Epidemiologi penyakit THT di 7 provinsi. Kumpulan makalah dan pedoman kesehatan telinga. Lokakarya THT Komunitas. PIT PERHATI-KL. Palembang. 2001; p. 8-12.
3. Yilmaz T, Kocan E, Besler HT. The role of oxidants and antioxidants in chronic tonsillitis and adenoid hypertrophy in children. International Journal of Pediatric Otorhinolaryngology. 2004; 68: p. 1053-8.

4. Brodsky L, Poje C. Tonsillitis, tonsillectomy, and adenoidektomi. In: Bailey BJ, Johnson JT, Newland SD editors. Head and Neck Surgery-Otolaryngology, $4^{\text {th }}$ ed, Vol I. Philadelphia: Lippincott Williams and Wilkins. 2006; p.1183-98.

5. Hendradewi, S. Hubungan kadar IFN-Gamma dengan kualitas hidup penderita tonsillitis kronik sebelum dan sesudah tonsilektomi. Tesis. PPDS 1 IKTHT-KL FK Undip Semarang. Undip. 2006. (belum dipublikasi)

6. Cvetkovic, T, Vlahovic P, Todorovic M, Stankovic M. Investigation oxidative stress in patien with chronic tonsillitis. Auris Nasus Larynx.2009;36(3): p. 340-4.

7. Padayatty S, Katz A, Wang Y, Eck P, Kwon O, Lee J, et al. Vitamin $\mathrm{C}$ as an antioxidant: evaluation of its role in disease prevention. Journal of The American College of Nutrition. 2003; 22(1): p. 18-35.

8. Huang H, Appel L, Croft K, Miller E, Mori T, Puddey I. Effects of vitamin $C$ and vitamin $E$ on in vivo lipid peroxidation: results of a randomized controlled trial. Am J Clin Nutr. 2002; 76: p.549-55.

9. Mohamed A, Sabry R, Ali H, Al-Refaey A. Assessment of malondialdehyde and ascorbic acid serum levels in group of egyptian children with chronic tonsillitis before and after tonsillectomy. Journal of American Science. 2012; 8(12): p.1321-5.

10. Abuhandan M, Bozkus F, Demir N, Eren E, Koca B, Guler OK, et al. The preoperative and postoperative oxidative status of children with chronic adenotonsillar hypertrophy. Clin Ter. 2013;164(3): p. 163-7.

11. Pashkow, FJ. Oxidative stress and inflammation in heart disease: do antioxidants have a role in treatment and/or prevention?. International Journal of Inflammation. 2011; p.1-9.

12. Aleszczyk J. Evaluation of vitamin and immune status of patients with chronic palatal tonsillitis. Otolaryngol Pol. 2001; 55(1): p. 65-7.

13. Hemila $\mathrm{H}, \mathrm{Al}-$ Biltagi $\mathrm{M}$, Baset A. Vitamin $\mathrm{C}$ and asthma in children: modification of the effect by age, exposure to dampness and the severity of asthma. Clinical an Translational Allergy. 2011; p.1-9.

14. Wager $\mathrm{T}$, Atlas $\mathrm{L}$. The neuroscience of placebo effects: connecting context, learning and health. Nature Reviews Neuroscience. 2015;16(7): p. 403-18.

15. Barrita J, Sanche S. Antioxidant role of ascorbic acid and his protective effects on chronic disease. In: Gonzalez JAM editor. Oxidative Stress and Chronic Degenerative Disease-A Role for Antioxidants, 1st ed. Rijeka: InTech. 2013; p. 459-501. 